\title{
PENGARUH ANTARA PENGGUNAAN VARIASI METODE MENGAJAR OLEH GURU EKONOMI TERHADAP MINAT BELAJAR PESERTA DIDIK
}

\author{
Ririn Dwi Septianti, Junaidi H. Matsum, Husni Syahrudin \\ Program Studi Pendidikan IPS FKIP UNTAN Pontianak \\ Email: ririnseptianti1996@gmail.com
}

\begin{abstract}
This thesis is entitled "The Influence of the Use of Variations in Teaching Methods by Economics Teachers on Students' Interest in Learning in Class XI SMA Negeri 10 Pontianak". The method used is descriptive method. With the results of the study as follows: 1) The use of variations in teaching methods by economics teachers at SMA Negeri 10 Pontianak can be concluded that the use of variations in teaching methods by economics teachers at SMA Negeri 10 Pontianak is very good. 2) Based on the results of the distribution of questionnaires and observations made by researchers, that the learning interest of class XI students at SMA Negeri 10 Pontianak is good. 3) The magnitude of the relationship between the use of variations in teaching methods by economics teachers and students' interest in learning at SMA Negeri 10 Pontianak is based on the results of correlation calculations. The product moment is 0.735 which, when confirmed in the guidelines for providing Interpretation, the correlation coefficient according to Sugiono is in the interval between 0.60-0.799, which means it has a strong level of relationship. Meanwhile, from the t-test, the t-count value is 6.664 while the t-table is 2.68, which means t-count $>$ t-table, thus showing a significant correlation.
\end{abstract}

\section{Keyword : The Use of Variations in Teaching Methods, Students' Interests in Learning, Economic Learning}

\section{PENDAHULUAN}

Dalam proses pembelajaran penggunaan metode pembelajaran serta model pembelajaran yang tepat akan mempermudah guru didalam menyampaikan materi pembelajaran kepada peserta didik, tetapi didalam pelaksanaannya kerap kali guru terkendala untuk menyampaikan materi pembelajaran yang bisa membuat peserta didik mudah menerima pembelajaran, hal ini dikarenakan terkendala dari penggunaan metode pembelajaran yang digunakan masih dirasakan bersifat konvensional, artinya pengunaan metode pembelajaran masih didomina dengan keaktifan guru, sementara peserta didik kurang aktif dalam proses pembelajaran.

Didalam pembelajran tentu guru haruslah mempersiapkan segala sesuai yang berkaitan dengan pembelajaran, baik dari mempersiapakan Rencana Pelaksanaan Pembelajaran, serta mempersiapakan media pembelajaran serta bahan ajar yang akan disampaikan, untuk mengapai tujuan pembelajaran yang ingin digapai, maka dibutuhkan keterampilan didalam menggunakan variasi metode dalam mengajar, banyak sekali metode pembeljaran yang sering digunakan oleh guru, baik metode ceramah, metode 
diskusi serta metode tanya jawab yang kerap kali digunakan oleh guru untuk menyampaikan pembelajaran, atau materimateri pembelajaran yang akan disampaikan.

Selama proses pembelajaran kerap kali guru tidak dapat menyampaikan pembelajaran secara maksimal, hal ini terkendala oleh metode mengajar yang digunakan terkandnag tidak pas dengan kondisi kelas, karena yang terlihat hanya guru yang aktif mengajar sementara peserta didik, kurang aktif didalam mengikuti pembelajaran yang berlangsung, metode ceramah yang digunakan guru, jika tidak di kombinasikan dengan metode mengajar yang lain, seperti tanya jawab serta diskusi tidak akan berjalan dengan baik atau diharapkan.

Guru merupakan salah satu komponen dalam proses belajar mengajar yang turut serta berperan dalam rangka menciptakan sumber daya manusia yang potensial di bidang pendidikan, guru juga bertanggung jawab untuk membawa peserta didik pada suatu perubahan yang lebih baik. Berkaitan dengan itu guru memiliki peranan sebagai pendidik dalam rangka meningkatkan minat dan pengembangan kegiatan belajar peserta didik.

Dalam proses pembelajaran, seorang guru dituntut kemampunnya untuk melakukan berbagai variasi dalam pembelajaran, adapun variasi pembelajaran yaitu variasi metode mengajar. Variasi metode mengajar adalah suatu kegiatan terarah, disiplin, yang dilakukan oleh guru ekonomi dalam rangka penyampaian pelajaran yang diajarkan berbeda-beda sesuai dengan keadaan dan karakteristik umum peserta didik di kelas. Penerapan variasi metode mengajar ini dilakukan dengan tujuan untuk menciptakan suasana belajar yang menyenangkan dan untuk menarik perhatian peserta didik terhadap pembelajaran. Selain itu penggunaan variasi metode mengajar dapat menghindari rasa bosan peserta didik tehadap pelajaran dan peserta didik dapat merasakan penyampaian materi dengan situasi yang berbeda. Dalam penelitian ini yang penulis titik beratkan adalah penggunaan variasi metode mengajar.

Dari hal-hal tersebut di atas, jelaslah bahwa begitu pentingnya penggunaan variasi metode mengajar khususnya pada pelajaran ekonomi, dengan tujuan untuk menumbuhkan minat belajar peserta didik dan menghilangkan rasa bosan peserta didik terhadap pelajaran tersebut sehingga tercipta kondisi belajar mengajar yang terarah dan terpadu pada sasaran yang dikehendaki dan yang ingin dicapai.

Seorang guru harus bisa memahami fungsi dan penggunaan variasi metode mengajar dan harus berusaha mewujudkan dalam melaksanakan proses pembelajaran, dan guru juga dapat menggunakan serta menyesuaikan variasi metode mengajar dengan materi yang diajarakan, menyesuaikan dengan waktu yang tersedia dan sikap peserta didik di kelas, sehingga hal ini akan mampu menumbuhkan minat belajar peserta didik untuk mengikuti pelajaran.

Minat merupakan salah satu faktor yang cukup menentukan dalam meningkatkan minat belajar peserta didik, dikatakan demikian karena minat merupakan modal dasar bagi peserta didik menyenangi atau tertarik untuk mempelajari pelajaran yang akan diajarkan kepadanya. Ditemukan minat belajar peserta didik menigkat apabila ada rangsangan-rangsangan yang diperoleh saat belajar, rangsangan yang dimaksud itu seperti pertanyaan yang dilontarkan guru, metode dan media pembelajaran yang digunakan guru dalam mengajar. Meningkatnya minat belajar peserta didik akan tampak pada pemusatan perhatian peserta didik terhadap pelajaran, keingintahuan peserta didik dan aktif 
dalam kegiatan dikelas misalnya melontarkan pertanyaan.

Apabila peserta didik melihat, mendengar dan merasakan atau mengalami peristiwa yang sama dan berulang terus menerus tiap hari, tanpa adanya sesuatu yang baru maka akan membuat peserta didik merasa bosan, jenuh dan tidak mengikuti pelajaran dengan baik, sehingga peserta didik tidak menyerap pelajaran dengan baik dan minat peserta didik untuk mengikuti proses pembelajaran tersebut menjadi berkurang. Berdasarkan hasil observasi yang penulis lakukan, penulis simpulkan bahwa penggunaan variasi metode mengajar oleh guru ekonomi sudah terlihat baik dan bervariasi, adapun variasi metode mengajar yang digunakan guru ekonomi SMA Negeri 10 pontianak yaitu metode ceramah, metode diskusi, dan metode tanya jawab. Begitupun minat belajar peserta didik mengikuti pelajaran boleh dikatakan antusias walaupun masih beberapa peserta didik yang kurang menunjukkan minatnya dalam proses belajar mengajar. Berdasarkan uraian diatas, peneliti ingin mengetahui seberapa besar tingkat "Pengaruh Antara Penggunaan Variasi Metode Mengajar Oleh Guru Ekonomi Terhadap Minat Belajar Peserta Didik Di Kelas XI SMA Negeri 10 Pontianak".

Dari latar belakang di atas, dapat dirumuskan masalah penelitian sebagai berikut "Bagaimanakah Pengaruh Antara Penggunaan Variasi Metode Mengajar Oleh Guru Ekonomi Terhadap Minat Belajar Peserta Didik Di Kelas XI SMA Negeri 10 Pontianak?"Adapun sub-sub masalah yang dapat penulis rumuskan adalah: 1) Variasi metode mengajar apa saja yang digunakan oleh guru Ekonomi pada peserta didik kelas XI SMA Negeri 10 Pontianak? 2) Tentang bagaimana minat belajar peserta didik kelas XI SMA Negeri 10 Pontianak dengan adanya variasi metode dalam pembelajaran?, 2)Apakah terdapat pengaruh signifikan antara penggunaan variasi metode mengajar oleh guru terhadap minat belajar peserta didik kelas XI Negeri 10 Pontianak?. Adapun yang menjadi tujuan penelitian untuk mendapatkan informasi yang jelas dan objektif mengenai hubungan antara penggunaan variasi metode mengajar oleh guru dengan minat belajar peserta didik kelas XI SMA Negeri 10 Pontianak. Sedangkan secara khusus, tujuan penelitian ini untuk mendapatkan informasi yang jelas dan objektif tentang:1) Variasi metode pengajaran yang dilakukan oleh guru ekonomi pada peserta didik kelas XI SMA Negeri 10 Pontianak. 2) Minat belajar peserta didik kelas XI SMA Negeri 10 Pontianak dengan adanya variasi metode mengajar.3) Pengaruh penggunaan variasi metode mengajar oleh guru ekonomi dengan minat peserta didik kelas XI SMA Negeri 10 Pontianak. Untuk menyatukan pandangan dan menghindari penafsiran yang berbeda terhadap istilah yang digunakan dalam penelitian ini, maka perlu adanya definisi operasional. Adapun definisi operasional yang dimaksud adalah:Penggunaan Variasi metode mengajar: Menggunakan variasi dalam mengajar diartikan sebagai perbuatan guru dalam konteks proses belajar mengajar yang bertujuan mengatasi kebosanan peserta didik sehingga dalam proses belajarnya peserta didik senantiasa menunjukkan ketekunan, keantusiasan, serta berperan secara aktif.

Dengan demikian, variasi dalam mengajar adalah salah satu upaya yang dilakukan seorang guru dalam proses pembelajaran yang kegiatannya bermacam-macam dan tujuannya adalah untuk memberikan pengalaman baru dalam belajar guna untuk mengatasi kejenuhan peserta didik serta memotivasi peserta didik untuk belajar, Penggunaan variasi 
metode mengajar dalam penelitian ini adalah penggunaan variasi metode mengajar yang digunakan oleh guru ekonomi SMA Negeri 10 Pontianak adalah: (1) Metode ceramah adalah sebuah metode mengajar dengan menyampaikan informasi dan pengetahuan saecara lisan kepada sejumlah peserta didik di kelas.(2) Metode diskusi adalah sebuah metode mengajar dimana guru memberikan kesempatan kepada peserta didik atau setiap kelompok peserta didik untuk mengumpulkan pendapat, menyusun alternatif pemecahan masalah dan membuat kesimpulan.(3) Metode tanya jawab adalah penyampaian pelajaran dengan cara guru mengajukan perrtanyaan dan murid menjawab;cara penyajian pelajaran dalam bentuk pertanyaan yang memerlukan jawaban,terutama dari guru kepada murid atau sebaliknya.Minat belajar peserta didik:Minat merupakan suatu keinginan yang ada pada diri seseorang untuk melakukan sesuatu. Minat sangat berpengaruh terhadap belajar sebab dengan minat sesorang memiliki keinginan untuk melakukan sesuatu diantaranya belajar. Dengan minat belajar yang tinggi maka proses belajar mengajar dapat berlansung dengan efektif dan efisien. Minat belajar dalam penelitian ini adalah ungkapan rasa ingin dari seorang peserta didik yang datang dari dalam maupun luar diri peserta didik untuk melakukan kegiatan berupa kegiatan belajar yang dinyatakan dengan perasaan tertarik dan senang untuk melakukan proses belajar mengajar pada pelajaran ekonomi di kelas XI SMA Negeri 10 Pontianak.

Dalam proses pembelajaran, seorang guru dituntut kemampunnya untuk melakukan berbagai variasi dalam pembelajaran, adapun variasi pembelajaran yaitu variasi metode mengajar. Variasi metode mengajar adalah suatu kegiatan terarah, disiplin, yang dilakukan oleh guru ekonomi dalam rangka penyampaian pelajaran yang diajarkan berbeda-beda sesuai dengan keadaan dan karakteristik umum peserta didik di kelas. Penerapan variasi metode mengajar ini dilakukan dengan tujuan untuk menciptakan suasana belajar yang menyenangkan dan untuk menarik perhatian peserta didik terhadap pembelajaran. Selain itu penggunaan variasi metode mengajar dapat menghindari rasa bosan peserta didik tehadap pelajaran dan peserta didik dapat merasakan penyampaian materi dengan situasi yang berbeda. Dalam penelitian ini yang penulis titik beratkan adalah penggunaan variasi metode mengajar.

Dari hal-hal tersebut di atas, jelaslah bahwa begitu pentingnya penggunaan variasi metode mengajar khususnya pada pelajaran ekonomi, dengan tujuan untuk menumbuhkan minat belajar peserta didik dan menghilangkan rasa bosan peserta didik terhadap pelajaran tersebut sehingga tercipta kondisi belajar mengajar yang terarah dan terpadu pada sasaran yang dikehendaki dan yang ingin dicapai.

Seorang guru harus bisa memahami fungsi dan penggunaan variasi metode mengajar dan harus berusaha mewujudkan dalam melaksanakan proses pembelajaran, dan guru juga dapat menggunakan serta menyesuaikan variasi metode mengajar dengan materi yang diajarakan, menyesuaikan dengan waktu yang tersedia dan sikap peserta didik di kelas, sehingga hal ini akan mampu menumbuhkan minat belajar peserta didik untuk mengikuti pelajaran.

Minat merupakan salah satu faktor yang cukup menentukan dalam meningkatkan minat belajar peserta didik, dikatakan demikian karena minat merupakan modal dasar bagi peserta didik menyenangi atau tertarik untuk mempelajari pelajaran yang akan diajarkan kepadanya. Ditemukan minat belajar 
peserta didik menigkat apabila ada rangsangan-rangsangan yang diperoleh saat belajar, rangsangan yang dimaksud itu seperti pertanyaan yang dilontarkan guru, metode dan media pembelajaran yang digunakan guru dalam mengajar. Meningkatnya minat belajar peserta didik akan tampak pada pemusatan perhatian peserta didik terhadap pelajaran, keingintahuan peserta didik dan aktif dalam kegiatan dikelas misalnya melontarkan pertanyaan.

Apabila peserta didik melihat, mendengar dan merasakan atau mengalami peristiwa yang sama dan berulang terus menerus tiap hari, tanpa adanya sesuatu yang baru maka akan membuat peserta didik merasa bosan, jenuh dan tidak mengikuti pelajaran dengan baik, sehingga peserta didik tidak menyerap pelajaran dengan baik dan minat peserta didik untuk mengikuti proses pembelajaran tersebut menjadi berkurang.

Dari hal-hal tersebut diatas jelaslah bahwa penggunaan variasi metode mengajar dapat menciptakan minat belajar peserta didik yang di pandang sebagai yang utama untuk mengembangkan potensi yang dimiliki oleh peserta didik. Oleh karena itu dalam proses pembelajaran peserta didik dituntut memiliki minat belajar yang tinggi agar peserta didik dapat mengikuti proses belajar dengan baik yaitu memahami dan mengerti pelajaran atau ilmu pengetahuan yang di pelajarinya.

\section{METODE PENELITIAN}

Didalam penelitian ini, metode penelitian yang digunakan berbentuk kuantitatif deskripsi, adapun yang menjadi populasi dalam penelitian ini adalah peserta didik serta guru ekonomi, di SMA Negeri 10 Pontianak, dalam penelitian ini alat pengumpul data yang digunakan berupa angket, kemudian.

\section{HASIL DAN PEMBAHASAN Hasil Penelitian}

Hasil dalam penelitian ini menunjukkan bahwa: 1) Penggunaan variasi metode mengajar oleh guru ekonomi SMA Negeri 10 Pontianak terdiri dari metode ceramah, metode diskusi dan metode Tanya jawab. Dari hasil angket observasi dan wawancara dapat disimpulkan bahwa penggunaan variasi metode mengajar oleh guru ekonomi SMA Negeri 10 Pontianak sangat baik. 2) Minat belajar siswa kelas XI SMA Negeri 10 Pontianak dilihat dari ketertarikan pada pelajaran ekonomi dan respon siswa pada pertanyaan dan tugas yang diberikan guru sudah terlihat baik. 3) Apakah terdapat pengaruh signifikan antara penggunaan variasi metode mengajar oleh guru terhadap minat belajar peserta didik kelas XI Negeri 10 Pontianak Adapun Besarnya berdasarkan hasil perhitungan sebesar 0.735 yang apabila dikonfirmasikan pada pedoman untuk memberikan pada interval antara 0.600.799 , yang berarti memiliki tingkat yang kuat.

\section{Pembahasan Penelitian}

Pembahasan penelitian tentunya berdasarkan hasil penelitian serta permasalahan penelitian sebagai berikut: 1) Penggunaan variasi metode mengajar oleh guru ekonomi SMA Negeri 10 Pontianak terdiri dari metode ceramah, metode diskusi dan metode Tanya jawab. Dari hasil angket observasi dan wawancara dapat disimpulkan bahwa penggunaan variasi metode mengajar oleh guru ekonomi SMA Negeri 10 Pontianak sangat baik. Hal ini dikarenakan didalam kegiatan pembelajaran berlangsung guru ekonomi mengkombinasikan metode pembelajaran, sehingga didalam proses pembelajaran peserta didik aktif dalam mengikuti pembelajaran. 
Hal ini senjalan menurut Zulfajri, EM dan Aprilia Ratu (2000) (Online) (http://lead.sabdaorg/pemikiran sekitar metode mengajar) (april 2019) "variasi yaitu selingan atau tindakan perubahan dari keadaan semula atau bentuk yang lain atau yang berbeda atau berbeda rupa atau hiasan tambahan agar ada perbedaan. Adapun metode menurut Wakhinuddin S adalah suatu sarana untuk menemukan, menguji dan menyusun data yang diperlukan bagi pengembangan disiplin tersebut.

(http://wakhinuddin.wordpress.com akses april 2019).

Sedangkan menurut Suryosubroto (2014:148) menyatakan bahwa: "metode pengajaran, adalah cara pelaksanaan proses pengajaran atau saat bagaimana teknisnya sesuatu bahan pelajaran diberikan kepada peserta didik atau murid-murid di sekolah.

2) Berdasarkan hasil penyebaran angket dan observasi yang dilakukan peneliti, bahwa minat belajar siswa kelas XI SMA Negeri 10 Pontianak dilihat dari ketertarikan pada pelajaran ekonomi dan respon siswa pada pertanyaan dan tugas yang diberikan guru sudah terlihat baik. Hal ini dikarena saat pelaksanaan pembelajaran guru ekonomi didalam menyampaikan materi pembelajaran disampaikan dengan menvariasikan metode mengajar, sehingga peserta didik tertarik mengikuti pembelajaran.

Berdasarkan teori "Acceptance Rejection" yang dikemukakan Fryer, (online) (http://Sobatbaru.blogspot.com diakses Oktober 2018)". bahwa keberadaan minat itu berdasarkan pada orientasi suka dan tidak sukanya individu terhadap objek, subjek atau aktivitas". Orientasi ini pada gilirannya akan mempengaruhi penerimaan individu. Jika individu suka terhadap objek, subjek, atau aktivitas tersebut, maka individu akan menerimanya. Jika individu tidak suka kepada objek, subjek atau aktivitas tersebut, maka ia akan menolaknya. Penentuan minat ini didasarkan pada reaksi individu (menolak/menerima). Jika ia menerima berarti ia berminat, dan jika menolak berarti ia tidak berminat.3) Adapun Besarnya pengaruh Penggunaan variasi metode Mengajar oleh guru ekonomi dengan minat belajar siswa SMA Negeri 10 Pontianak berdasarkan hasil perhitungan korelasi produc moment sebesar 0.735 yang apabila dikonfirmasikan pada pedoman untuk memeberikan Interprestasi koefisien korelasi menurut Sugiono berada pada interval antara 0.60-0.799, yang berarti memiliki tingkat hubungan yang kuat. Sedangkan dari uji $\mathrm{t}$ diperoleh nilai $\mathrm{t}$ hitung sebesar 6,664 sedangkan $t$ tabel sebesar 2,68 yang berarti t hitung > t tabel, sehingga menunjukan korelasinya signifikan.

Variasi metode mengajar yang dilaksanakan di sekolah perlu diberikan oleh guru pendidikan ekonomi pada peserta didiknya dalam proses belajar mengajar. Agar anak didik tersebut setiap mengikuti pelaksanaan pembelajaran tidak merasa bosan dikarenakan metode yang tidak bevariasi. Selain itu dapat meningkatkan minat belajar peserta didik sehingga proses pembelajaran di kelas dapat berjalan dengan efektif dan dapat menggembangkan potensi belajar peserta didik.

Selain itu tujuan variasi metode mengajar juga harus dapat meningkatkan dan memelihara perhatian peserta didik terhadap relevansi proses belajar mengajar, dalam proses belajar mengajar perhatian dari peserta didik terhadap materi pelajaran sangat dituntut sehingga tercapainya tujuan pembelajaran. Indikator penguasaan peserta didik terhadap materi pelajaran adalah tejadinya perubahan dalam diri peserta didik, jadi perhatian adalah 
masalah yang tidak biasa dikesampingkan dalam konteks pencapaian tujuan pembelajaran.

\section{SIMPULAN DAN SARAN Simpulan}

Berdasarkan dari hasil penelitian yang dilakukan di SMA Negeri 10 Pontianak maka dapat ditarik kesimpulan dari hasil penyebaran angket, hasil wawancara dan hasil pengamatan. Adapun kesimpulan yang dapat ditarik oleh peneliti adalah sebagai berikut:1) Penggunaan variasi metode mengajar oleh guru ekonomi SMA Negeri 10 Pontianak terdiri dari metode ceramah, metode diskusi dan metode Tanya jawab. Dari hasil angket observasi dan wawancara dapat disimpulkan bahwa penggunaan variasi metode mengajar oleh guru ekonomi SMA Negeri 10 Pontianak sangat baik. 2) Minat belajar siswa kelas XI SMA Negeri 10 Pontianak dilihat dari ketertarikan pada pelajaran ekonomi dan respon siswa pada pertanyaan dan tugas yang diberikan guru sudah terlihat baik.3) Apakah terdapat pengaruh signifikan antara penggunaan variasi metode mengajar oleh guru terhadap minat belajar peserta didik kelas XI Negeri 10 Pontianak Adapun Besarnya berdasarkan hasil perhitungan sebesar 0.735 yang apabila dikonfirmasikan pada pedoman untuk memberikan pada interval antara 0.60-0.799, yang berarti memiliki tingkat yang kuat.

\section{Saran}

Berdasarkan dengan kesimpulan di atas, maka hal-hal yang sebaiknya dilakukan agar kegiatan kebudayaan etnis dapat berjalan dengan baik adalah sebagai berikut. Bagi siswa,

Diharapkan menyadari bahwa pelajaran ekonomi sangatlah penting untuk dipelajari karena pelajaran ekonomi merupakan ilmu yang mempelajari tentang kebutuhan sehari-hari, selain itu hendaknya siswa harus aktif dalam kegiatan dikelas seperti menyampaikan ide pada saat diskusi, bertanya kepada guru apabila ada kesulitan atau kurang mengerti dalam materi yang diajarkan guru dan menjawab pertanyaan dari guru maupun siswa lainnya.Bagi pihak sekolah, Diharapkan dapat memberikan motivasi supaya segala kesulitan atau kekurangan yang dialami guru dan siswa dalam memperoleh media atau sarana dan prasarana yang diperlukan dalam proses pembelajaran dapat diatasi demi kemajuan siswa dan sekolah.

\section{DAFTAR RUJUKAN}

Alpandie, I. (2011). Didaktik Metodik Pendidikan Umum, Surabaya: Usaha Nasional.

Arikunto, S, (2012), Prosedur Penelitian Suatu Pendekatan Praktik, Jakarta: PT. Adi Mahasatya.

Boekes (dalam Mar'at 1984:110). Teori Tentang Aktif Kegiatan di Kelas.".(online) (www.snapdrive.net. dakses maret 2021).

Dimayati, dan Mudjiono. (2013) Belajar dan Pembelajaran. Jakarta: Rineka Cipta

D,Dierich (dalam Oemar Hamalik 2001: 172). Proses Belajar Mengajar (online) (http://one.indoskripsi.com diakses maret 2021)

Fryer, (2008). Tinjauan Tentang Minat Belajar (online) (http://Sobatbaru.blogspot.com diakses 2021)"

Hamalik, O, (2008), Proses Belajar Mengajar, Jakarta: PT Bumi Aks

Mantra dan Kastra (dalam Singarimun dan Efendi), (1989). Arti Statistik (Online) (http://www.guruvalah.20m.com.artistat istik.pd.2021). 
Nawawi. H.(2007), Metodologi Penelitian Bidang Sosial, Yogyakarta: Gadjah Mada University Press.

Prianto S., (2001) Kamus Lengkap Bahasa Indonesia. Jakarta: Balai Pustaka

Roestiyah N.K (2009), Didaktik Metodik, Jakarta: Bina aksara.

Roijakers. (1980). Tinjauan Tentang Minat Belajar Peserta didik. (Online).(http://sobatbaru.blogspot.com diakses 2021).

Saedah. (2006). Hubungan Minat Belajar Dengan Hasil Belajar Peserta didik Pada Mata Pelajaran IPS Ekonomi Di Kelas II SMP Negeri Ambalau Kabupaten Sintang. Pontianak : Universitas Tanjungpura.

Salahudin, M. Tinjauan Tentang Minat Belajar Peserta didik. (Online).(http://sobatbaru.blogspot.com dakses 2021).

Slameto, (2003). Belajar Dan Faktorfaktor Yang Mempengaruhi. Jakarta: PT. Rineka Citra.

Sugiyono, (2018). Metode Penelitian Pendidikan, Bandung: Penerbit Alfabeta.

Sumanto, W, (1984). Minat Belajar (online)

(http://naomiputri.blogspot.com (diakses 2019)

Surakhmad, W. Metode Mengajar (http://www.psbpsma.org/content/blog/strategi-metodemengajar akses maret 2021.

Tim. (2019). Pedoman Penulisan karya Ilmiah, Pontianak: Edukasi Pres FKIP UNTAN

Tini, W, (2008). Hubungan Pemberian Penguatan Oleh Guru Pendidikan Kewarganegaraan Dengan Minat Belajar Peserta didik Dalam Proses Belajar Mengajar di Kelas X Sekolah Menegah Kejuruan Negeri 1 Pontianak : STKIP-PGRI Pontianak)
Undang-Undang Republik Indonesia No. 20 tahun 2003 dan Undang-Undang No 14 tahun 2005. (2007). Sistem Pendidikan Nasional, Guru dan Dosen. Jakarta:Visimedia.

Usman, M. U. (2007). Menjadi Guru Profesional, Bandung: PT.Remaja Rosdakarya.

Wakhinudin S. Metode Mengajar. (online) (Wakhinudin,Wordpress.com akses 2018)

Wahab A.Z.(2007) Metode Dan ModelModel Mengajar Ilmu Pengetahuan Sosial, Bandung: PT Alfabeta.

Withering T.A. (2002). Buku Materi Pokok PGSD 4302/4 SKS Modul 1-12: Universitas terbuka.ton (1980). Tinjauan Tentang Minat Belajar (online) http://sobatbaru.blogspot.com/2009/10/t injauan-tentang-minat-belajar-peserta didik.html)

Zulfajri EM dan Aprilia Ratu. Pemikiran Sekitar Metode Mengajar. (Online) (http://Lead.Sabda.Org/pemikiran) (diakses 2019). 